\title{
GENERAL PROPERTIES OF BIOTIN UPTAKE SYSTEM IN LIPOMYCES STARKEYI
}

\author{
YASUYUKI UZUKA, TAKAFUMI NAGANUMA, AND KENTARO TANAKA
}

Department of Fermentation Technology, Faculty of Engineering, Yamanashi University, Kofu, Yamanashi 400

(Received September 30, 1974)

The properties of the biotin uptake system of Lipomyces starkeyi IAM 4753 were investigated in proliferating and nonproliferating cells from the standpoint of explaining the characteristics of the biotin-requiring property of the organism in a medium with a pH from 5.5 to 6.5. The rate of biotin uptake was linear with time for at least the first $6 \mathrm{hr}$. Uptake of ${ }^{14} \mathrm{C}$-biotin showed the system to be an aeration- and energy sourcedependent process. This was confirmed by the almost complete inhibition of biotin uptake with $1 \mathrm{~mm}$ of 2, 4-dinitrophenol, potassium cyanide, and sodium azide.

Biotin uptake is $\mathrm{pH}$-dependent, and the optimum condition for uptake is a $\mathrm{pH}$ of 4.2. Biotin uptake is operative between a $\mathrm{pH}$ of 5.5 and 6.5 , and thus L. starkeyi IAM 4753 can grow in a medium with a $\mathrm{pH}$ from 5.5 to 6.5 , when biotin is supplemented. The uptake of biotin by the cells is influenced by the biotin concentration in the medium employed. The greatest uptake was observed when the cells were grown in a minimal medium without any supplementation of biotin.

Apparent activity for biotin uptake per $\mathrm{mg}$ dry cell was considerably influenced by culture age. The amount of ${ }^{14} \mathrm{C}$-biotin taken up by $\mathrm{mg}$ dry cell harvested during the logarithmic phase was the highest, decreasing gradually as the growth phase proceeded.

SLooff studied the growth of strains of Lipomyces starkeyi in a vitamin-free medium and concluded that the strains which do not grow in the medium require biotin essentially (1). During the course of studies on the nutritional requirement of L. starkeyi IAM 4753, we have demonstrated that the biotin-requiring property of the strain depends on the initial $\mathrm{pH}$ value of the medium (2). More recent work (3) from our laboratory has presented an evidence that biotin biosynthesis in L. starkeyi IAM 4753 is initiated when the $\mathrm{pH}$ value of the medium falls below 5.5. On the other hand, when the strain was grown in a glucose-mineral medium 
supplemented with biotin, the strain exhibited a normal growth profile, even in a medium with a $\mathrm{pH}$ of 6.5 (2). As a result of this, it is worthwhile to consider whether the biotin transport system of the strain might be active even at a $\mathrm{pH}$ of 6.5.

The present work was initiated to consider this problem and to obtain concrete experimental evidence that the biotin transport system is in fact operative at a $\mathrm{pH}$ as high as 6.5. Special attention was given to determine the dependence of the biotin transport system on the $\mathrm{pH}$. Initial experiments were carried out by using microbioassay for the measurement of biotin uptake. Later studies were performed with radioactive biotin which permitted a more precise measurement of the biotin uptake from the reaction mixtures.

\section{MATERIALS AND METHODS}

Carbonyl-labeled ${ }^{14} \mathrm{C}$-biotin $(58 \mathrm{mCi} / \mathrm{mmol}$ or $237 \mu \mathrm{Ci} / \mathrm{mg}$ ) was obtained from the Radiochemical Centre, Amersham. The labeled biotin was $98 \%$ pure, checked by microbiological assay and by paper chromatography (4). Other chemicals were of the highest grade from commercial sources.

The organism used throughout this work was Lipomyces starkeyi IAM 4753, the same strain employed in the previous work $(2,3,5)$. L. starkeyi IAM 4753 was grown aerobically at $30^{\circ}(2)$ on the minimal medium of WICKERHAM (6). The medium contained $1.0 \%$ glucose as the sole carbon source and, unless otherwise noted, $2 \mu \mathrm{g}$ of biotin per liter.

Some studies were performed with a bufferized medium, which was described in the previous paper (2). The cells were harvested at an optical density of approximately 1.0 at $660 \mathrm{~nm}$, washed twice with distilled water, and resuspended in distilled water to an optical density of 1.00 at $660 \mathrm{~nm}$. The cell suspension with an optical density of 1.00 at $660 \mathrm{~nm}$ showed an average dry cell weight of $0.95 \mathrm{mg} / \mathrm{ml}$. Samples $(5.0 \mathrm{ml})$ of this suspension were added to $5.0 \mathrm{ml}$ of double-strength reaction mixtures contained in 30-ml test tubes. Unless indicated otherwise, the final composition of the standard reaction mixture was $23.8 \mathrm{nCi}(100 \mathrm{ng})$ of ${ }^{14} \mathrm{C}$-biotin, $4.5 \mathrm{or}$

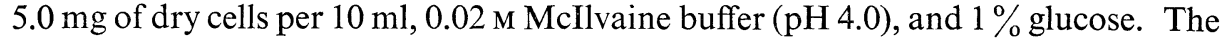
cell suspensions and the double-strength reaction mixtures were temperatureequilibrated in a water bath at $30^{\circ}$ before mixing.

Incubation was carried out at $30^{\circ}$ for $3 \mathrm{hr}$ with constant shaking. After incubation, reaction mixtures were transferred to heavy-walled glass centrifuge tubes and the reaction was stopped by immediate centrifugation at $2,000 \times g$ for $10 \mathrm{~min}$ at room temperature. The supernatant of reaction mixtures was decanted, and the centrifuge tubes were drained well. The cells were washed twice with distilled water, and the tubes were drained well and wiped. The cells were resuspended in distilled water to a volume of $2.0 \mathrm{ml}$. All samples ( $0.2 \mathrm{ml}$ of cell suspension) were placed in counting vials to which was added $10 \mathrm{ml}$ of liquid scintillator. The liquid scintillator was composed of toluene $(7.0 \mathrm{ml})$, ethanol $(2.9 \mathrm{ml}), 2,5$-diphenyloxazole 
(40 mg), and 1, 4-bis [2-(5-phenyloxazolyl)] benzene (1 mg) (7). Radioactivity was measured by the Horiba Model LS-550 liquid scintillation counter. Corrections for quenching were made by using the external standard, and counts per minute was converted to biotin concentration.

\section{RESULTS}

Effect of incubation conditions on the biotin uptake

Cells were grown in the minimal medium of WICKERHAM(6) and were harvested, washed twice in distilled water, and resuspended to an optical density of 0.10 at $660 \mathrm{~nm}$ in the minimal medium containing $2 \mu \mathrm{g}$ of biotin per liter and incubated both under shaking condition and under standing condition. Biotin concentration of the medium was estimated by microbiological assay (2). The data in Fig. 1 show that a decrease of biotin concentration occurred under shaking condition

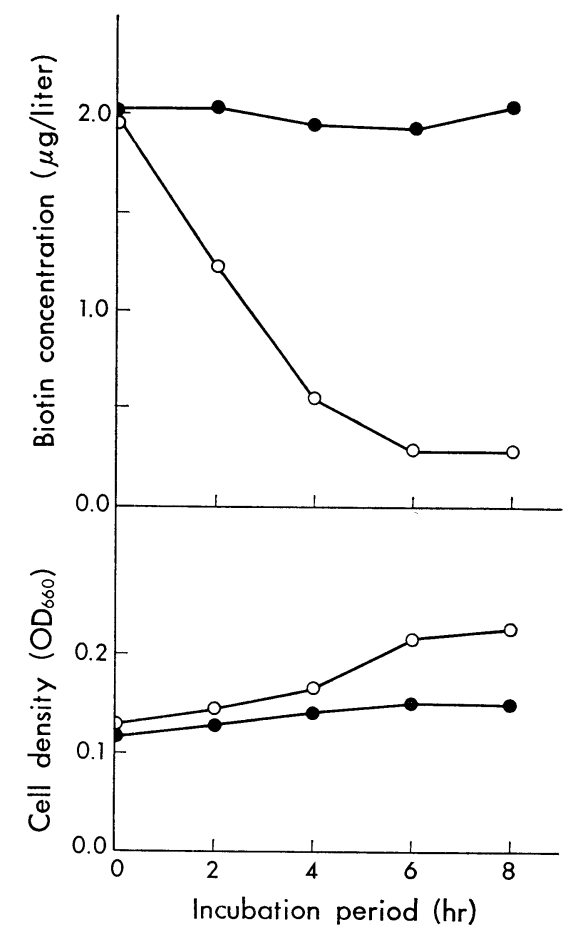

Fig. 1. Change of biotin concentration in a glucose-mineral medium supplemented with biotin.

Cell suspensions of $L$. starkeyi were prepared as described in the text. The cell suspensions were incubated at $30^{\circ}$, some with constant shaking and some without. Growth was measured by optical density. Biotin concentration was determined by microbiological assay. $\bigcirc-\bigcirc$, with shaking; - without shaking. 


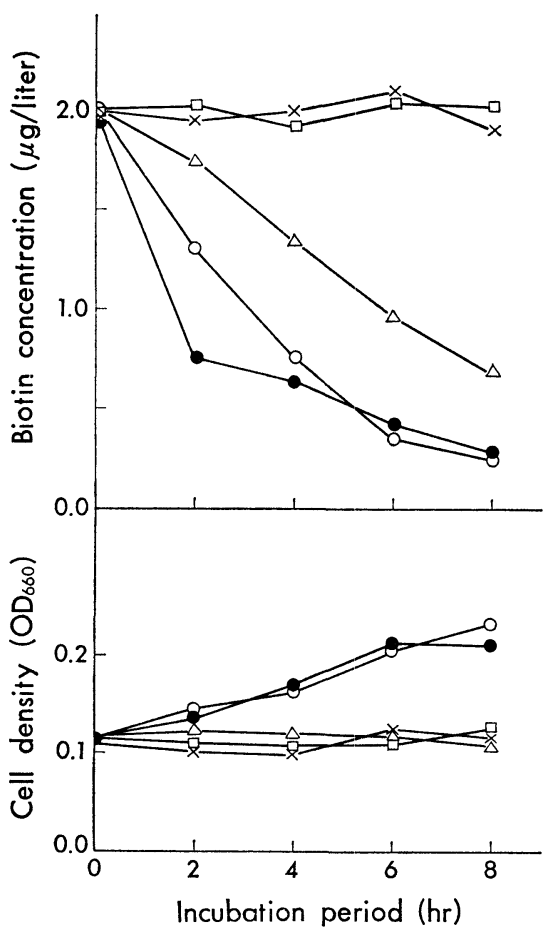

Fig. 2. Effect of glucose and nitrogen source on changes in the biotin concentration in growth media.

The medium employed was the minimal medium of Wickerham, supplemented with $2 \mu \mathrm{g}$ of biotin per liter. Cells were incubated at $30^{\circ}$ with constant shaking. Growth was measured by optical density. Biotin concentration was determined by microbiological assay. $\bigcirc-\bigcirc$, minimal medium of Wickerham; - - , minimal medium of Wickerham without $\left(\mathrm{NH}_{4}\right)_{2} \mathrm{SO}_{4} ; \times-\times$, minimal medium of Wickerham without glucose; $\square-\square$, minimal medium of Wickerham without both $\left(\mathrm{NH}_{4}\right)_{2} \mathrm{SO}_{4}$ and glucose; $\triangle-\triangle$, McIlvaine buffer ( $\mathrm{pH} 4.0$ ) supplemented with $0.5 \%$ of glucose.

and then the concentration reached a steady state. During incubation, a considerable growth of the cells was observed. Decrease of biotin concentration did not occur under standing condition. To make a simpler incubation mixture, effects of glucose and nitrogen source on the decrease of biotin concentration in the medium were determined (Fig. 2). Cells were incubated under shaking condition. Decrease of biotin concentration occurred when glucose was added to the reaction mixture. Growth was not observed when the cells were incubated in McIlvaine buffer solution.

This work was carried out to determine the characteristics of the biotin-requiring properties of Lipomyces starkeyi IAM 4753, as dependent on $\mathrm{pH}$ of the growth medium. At the beginning of these experiments, we planned to investigate the biotin uptake system in a state as similar to the growing stage as possible. As 
shown in Fig. 1, initial experiments on the uptake system were performed using a growth medium which contained $2 \mu \mathrm{g}$ of biotin per liter; the amount of biotin decreasing in the medium was considered as the amount of biotin taken up by the cells, but the rate of biotin taken up was slower than that expected. Variations in biotin content after incubation, however, did not exceed $10 \%$ of the initial biotin content in the cells. No clear-cut data were obtained by measurement of biotin content in the cells by a microbiological assay to explain the biotin uptake.

\section{Uptake of ${ }^{14} \mathrm{C}$-biotin as a function of time}

Radioactive biotin was employed as a direct means of measuring biotin uptake. The amount of radioactive biotin used in a $10-\mathrm{ml}$ reaction mixture was $100 \mathrm{ng}$ $(10 \mu \mathrm{g} /$ liter $)$. This amount was decided after considering the specific activity of radioactive biotin and the measuring procedures.

The uptake of ${ }^{14} \mathrm{C}$-biotin by the cells and dissipation of radioactivity in the Supernatant fluid over the course of time are shown in Fig. 3. The biotin uptake

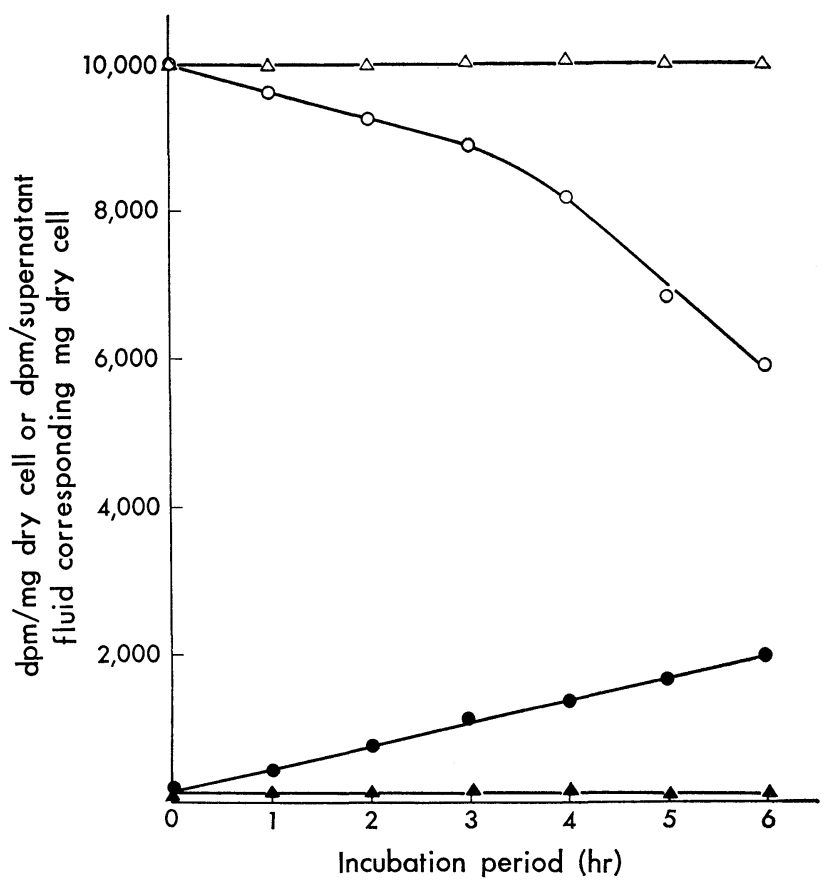

Fig. 3. Time dependence of biotin uptake

Cells equivalent to $0.45 \mathrm{mg}$ (dry weight) per $\mathrm{ml}$ were incubated in reaction mixtures containing $10 \mathrm{ng}$ of ${ }^{14} \mathrm{C}$-biotin per $\mathrm{ml}$, some with constant shaking and some without. The radioactivity of cell fractions and supernatant fluids was determined at the indicated time. $\bigcirc-\mathrm{O},{ }^{14} \mathrm{C}$-biotin in supernatant fluid incubated with shaking; $\triangle-\triangle,{ }^{14} \mathrm{C}$-biotin in supernatant fluid incubated without shaking: $-0,{ }^{14} \mathrm{C}$-biotin in cell fraction incubated with shaking; $\mathbf{\Delta}-\mathbf{\Delta},{ }^{14} \mathrm{C}$-biotin in cell fraction incubated without shaking. 
proceeded essentially in a linear fashion for $6 \mathrm{hr}$ under shaking condition. The disappearance of radioactivity from the Supernatant fluid under shaking condition proceeded linearly for $3 \mathrm{hr}$, and its rate was almost identical with the uptake rate of ${ }^{14} \mathrm{C}$-biotin by the cells.

However, after the incubation time proceeded more than $3 \mathrm{hr}$, the linearity of disappearance of radioactivity from the Supernatant fluid no longer held, presumably owing to the decomposition of the carbonyl group of radioactive biotin.

Figure 3 also shows the biotin uptake by the cells under standing condition. It appears, however, that there is no appreciable uptake by the cells under standing condition.

\section{Necessity of aeration for biotin uptake}

To confirm that aerobic condition is essential for the biotin uptake, tubes were bubbled with air, nitrogen, or carbon dioxide during the incubation period. The necessity of aeration for biotin uptake is outlined in Table 1. The cells bubbled with nitrogen or with carbon dioxide took up only about one-fifth or one-sixth of the biotin taken up by the cells bubbled with air.

Table 1. Requirement of aeration for biotin uptake.

Cells equivalent to $0.5 \mathrm{mg}$ (dry weight) per ml were incubated at $30^{\circ}$ in a reaction mixture containing $10 \mathrm{ng}$ of ${ }^{14} \mathrm{C}$-biotin per $\mathrm{ml}$ and $0.5 \%$ of glucose. Incubation was carried out for $3 \mathrm{hr}$ in 30-ml test tubes bubbled with air, nitrogen, or carbon dioxide.

\begin{tabular}{|c|c|c|}
\hline \multicolumn{2}{|c|}{ Bubbled with (ml/min) } & \multirow{2}{*}{$\frac{\text { Biotin taken up }(\mathrm{pmol} / \mathrm{mg} \text { dry cell } / \mathrm{hr})}{2.72}$} \\
\hline \multirow{4}{*}{ Air } & 100 & \\
\hline & 210 & 3.57 \\
\hline & 600 & 3.23 \\
\hline & 950 & 3.34 \\
\hline $\mathrm{N}_{2}$ & 900 & 0.53 \\
\hline $\mathrm{CO}_{2}$ & 520 & 0.65 \\
\hline
\end{tabular}

\section{Energy requirement for biotin uptake}

Many microbial vitamin transport systems depend on, or are stimulated by, the presence of an energy source $(8,9,10)$. The presence of $1 \%$ of glucose caused a 4-fold increase in the amount of biotin taken up after $3 \mathrm{hr}$ of incubation (Table 2). In this experiment stimulation by glucose depended on the concentration of glucose. Table 2 also shows that galactose and sucrose stimulated biotin uptake but that lactose and glycerol did not. To cross-check the results obtained with aeration and energy-yielding substrates, the effect of metabolic inhibitors on the uptake of ${ }^{14} \mathrm{C}$-biotin was determined. The cell suspensions were preincubated for $15 \mathrm{~min}$ at $30^{\circ}$ with 2, 4-dinitrophenol (DNP), sodium azide, or potassium cyanide added at concentrations indicated in Table 3. After preincubation, double-strength reaction mixtures were added and subsequent incubation followed for $3 \mathrm{hr}$ at $30^{\circ}$. 
Table 2. Effect of energy-yielding substrate on ${ }^{14} \mathrm{C}$-biotin uptake.

Cells were incubated for $3 \mathrm{hr}$ at $30^{\circ}$ in a reaction mixture containing $10 \mathrm{ng}$ of ${ }^{14} \mathrm{C}$ biotin per $\mathrm{ml}$ and $0.5 \%$ of energy-yielding substrate.

\begin{tabular}{cllc}
\hline Experimental number & \multicolumn{2}{l}{ Energy source $(\%)$} & $\begin{array}{c}\text { Biotin taken up } \\
\text { (pmol/mg dry cell/hr) }\end{array}$ \\
\hline \multirow{3}{*}{ I } & None & & 0.52 \\
& Glucose & 0.01 & 1.18 \\
& $" \prime$ & 0.1 & 2.72 \\
& $" \prime$ & 0.5 & 3.09 \\
& " & 1.0 & 3.49 \\
\hline \multirow{3}{*}{ II } & None & & 0.67 \\
& Glucose & 1.0 & 2.82 \\
& Galactose & 1.0 & 1.41 \\
& Sucrose & 1.0 & 1.08 \\
& Lactose & 1.0 & 0.66 \\
& Glycerol & 1.0 & 0.52 \\
\hline
\end{tabular}

Table 3. Inhibition of ${ }^{14} \mathrm{C}$-biotin uptake by metabolic inhibitors.

Metabolic inhibitors were added to cell suspensions and preincubated for $15 \mathrm{~min}$ at $30^{\circ}$. After preincubation, double-strength reaction mixtures were added and incubated for $3 \mathrm{hr}$ at $30^{\circ}$.

\begin{tabular}{cccc}
\hline Addition (mM) & \multicolumn{2}{c}{$\begin{array}{c}\text { Biotin taken up } \\
\text { pmol/mg dry cell/hr) }\end{array}$} & Inhibition (\%) \\
\hline \multicolumn{2}{c}{ None (control) } & 2.32 & 95 \\
$\mathrm{KCN}$ & 1.0 & 0.10 & 99 \\
$\mathrm{DNP}$ & 1.0 & 0.02 & 99 \\
$\mathrm{DNP}$ & 0.1 & 0.02 & 99 \\
$\mathrm{NaN}_{3}$ & 1.0 & 0.02 & 99 \\
$\mathrm{NaN}_{3}$ & 0.1 & 0.02 & 9 \\
\hline
\end{tabular}

The uptake of ${ }^{14} \mathrm{C}$-biotin was inhibited almost completely with $1 \mathrm{~mm}$ of these inhibitors.

\section{Effect of $p H$ on biotin uptake}

Biotin uptake was influenced by the $\mathrm{pH}$ of the reaction mixture as shown in Fig. 4. The optimum $\mathrm{pH}$ was 4.2. Biotin uptake was observed in the $\mathrm{pH}$ range of 2.0 to 8.0.

\section{Effect of biotin concentration}

The rate of biotin uptake increased with increasing external biotin concentration (Fig. 5), tending to become saturated at high extracellular concentrations. The apparent $\mathrm{Km}$ calculated from Lineweaver-Burk plot of the data was $5.6 \times$ $10^{-8} \mathrm{M}$. 


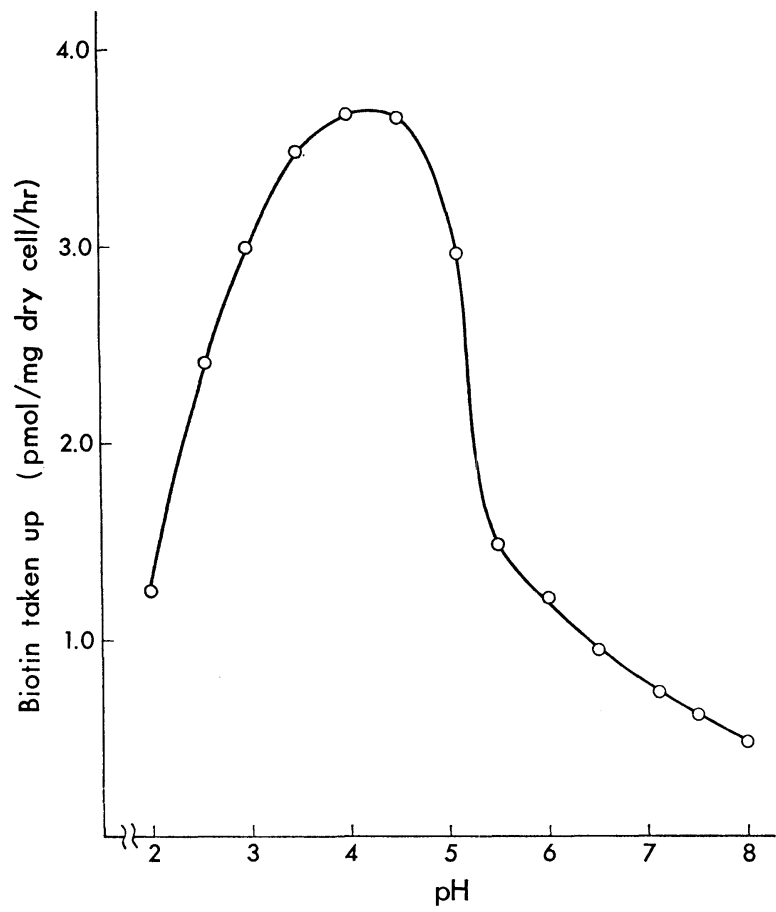

Fig. 4. Dependence of biotin uptake on $\mathrm{pH}$

Cells equivalent to $0.5 \mathrm{mg}$ (dry weight) per $\mathrm{ml}$ were incubated in reaction mixtures of the indicated $\mathrm{pH}$ values containing $10 \mathrm{ng}$ of ${ }^{14} \mathrm{C}$-biotin per $\mathrm{ml}$. Radioactivity was determined after $3 \mathrm{hr}$ of incubation.

\section{Effect of culture age on biotin uptake}

Since a morphological change of $L$. starkeyi has been observed with culture age $(11,12)$, it was of interest to determine whether the capacity to transport biotin varied greatly in cells of different ages. As Lipomyces starkeyi has an average generation time of $4.5 \mathrm{hr}$ under the culture conditions employed, it takes about $70 \mathrm{hr}$ to reach the stationary phase of growth. To facilitate the mechanics of the experiment, shaking flasks with the same medium were prepared and were inoculated at certain intervals. Cells at various culture stages were harvested, and their capacities for biotin uptake were determined (Fig. 6). The amounts of biotin taken up by the cells harvested at the logarithmic phase of growth were the highest, decreasing gradually as the growth phase progressed.

Influence of biotin in the growth medium on the capacity for biotin uptake

Lipomyces starkeyi exhibited normal growth profiles in simple glucose-mineral media with an initial $\mathrm{pH}$ ranging from 2.6 to 5.5 (2). This indicates that the yeast 


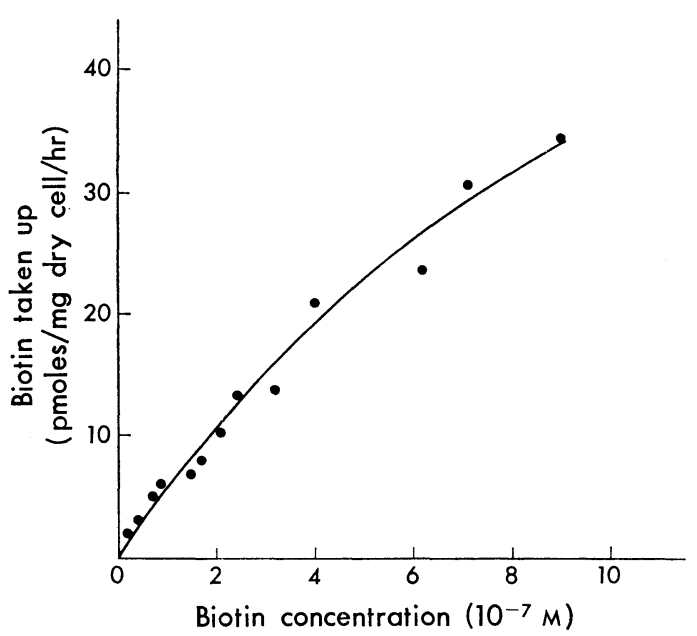

Fig. 5. Effect of biotin concentration on biotin uptake

Cells equivalent to $0.5 \mathrm{mg}$ (dry weight) per $\mathrm{ml}$ were incubated in reaction mixtures containing ${ }^{14} \mathrm{C}$-biotin at indicated concentrations. Radioactivity was determined after $3 \mathrm{hr}$ of incubation.

can synthesize biotin under these conditions. On the other hand, when the yeast was grown in media with a $\mathrm{pH}$ of 6.0 , biotin was essential for the growth (2), and the minimum amount of biotin required for normal growth was $0.1 \mu \mathrm{g} / \mathrm{liter}$ (3). In addition to this, the yeast did not remove more than $5 \mu \mathrm{g}$ of biotin from 1 liter of the medium even though an excess amount of biotin was added (3). From these results, it is of interest to compare the cells deficient in biotin to those with an excess of biotin for their ability to take up biotin.

Results are shown in Table 4. In the first experiment, cells were grown in glucose-mineral media with an initial $\mathrm{pH}$ of 4.0. The cells which were grown in the medium supplemented with biotin exhibited about one-sixth of capacity for biotin uptake compared with the cells grown in a simple glucose-mineral medium. In the second experiment, cells were grown in bufferized media with a $\mathrm{pH}$ of 6.0 and with a wide range of biotin concentrations. Except for the instance of lowest biotin concentration, growth was essentially the same at each level of vitamin concentration. Cells harvested from the biotin-deficient media ( 0.05 and $0.1 \mu \mathrm{g} /$ liter $)$ had the ability to take up significant amount of biotin. The capacity for biotin uptake in cells grown in biotin-sufficient media ( 2.0 and $20 \mu \mathrm{g} /$ liter) existed, although the amounts of biotin taken up were reduced.

\section{DISCUSSION}

From the results of our previous work $(2,3)$, the biotin uptake system in Lipo- 


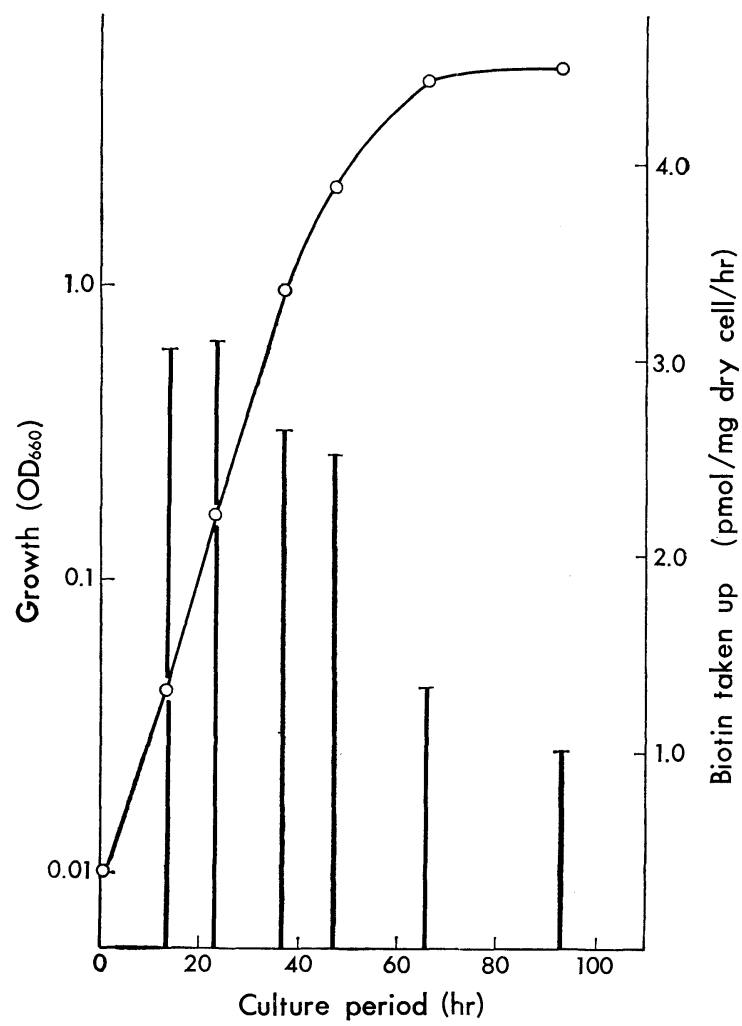

Fig. 6. Change of biotin uptake with culture age

Growth was followed by turbidimetry. At the indicated time intervals, samples were removed and biotin uptake was measured by incubating washed cells in a reaction mixture containing $10 \mathrm{ng}$ of ${ }^{14} \mathrm{C}$-biotin per $\mathrm{ml}$. Radioactivity was determined after $3 \mathrm{hr}$ of incuba-

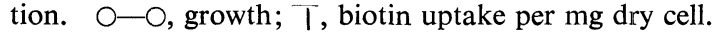

Table 4. Effect of biotin concentration in the growth media on ${ }^{14} \mathrm{C}$-biotin uptake.

The cells were grown in media containing various amounts of biotin. Cells were harvested at a late logarithmic phase of growth and were washed twice with distilled water. Washed cells were incubated for $3 \mathrm{hr}$ at $30^{\circ}$ in the reaction mixture containing $10 \mathrm{ng}$ of ${ }^{14} \mathrm{C}$-biotin per $\mathrm{ml}$.

\begin{tabular}{lcc}
\hline Medium employed & $\begin{array}{c}\text { Supplementation with biotin } \\
(\mu \mathrm{g} / \text { liter })\end{array}$ & $\begin{array}{c}\text { Biotin taken up } \\
(\mathrm{pmol} / \mathrm{mg} \text { dry cell/hr })\end{array}$ \\
\hline Glucose-mineral medium & 0.0 & 9.62 \\
of $\mathrm{pH} 4.0$ & 2.0 & 1.52 \\
\hline Bufferized medium of $\mathrm{pH}$ & 0.05 & 3.45 \\
6.0 & 0.1 & 2.97 \\
& 2.0 & 0.73 \\
& 20.0 & 0.87 \\
\hline
\end{tabular}


myces starkeyi IAM 4753 seems to be operative in a medium with a $\mathrm{pH}$ of 6.5 . Figure 4 in the present paper shows that biotin uptake by nonproliferating cells of L. starkeyi IAM 4753 occurred in the $\mathrm{pH}$ range of 2.0 to 8.0 but was affected by $\mathrm{pH}$ of the reaction mixture. The optimum $\mathrm{pH}$ was 4.2. Small amounts of biotin were removed from the cells throughout the experiments by washing with distilled water. This fact indicates that biotin which was taken up by the cells was immediately transported into the cells to be changed into the bound form of biotin. The formation of bound-form biotin might be little affected by the $\mathrm{pH}$ of the media used. In the previous growth experiments $(2,3)$, cells did not show substantial growth in a medium with a $\mathrm{pH}$ above 6.5 , even with a supplementation of biotin. Under such a condition, some physiological damage, other than biotin uptake, might have occurred in the cells.

ROGERS and LICHSTEIN (4) studied the biotin uptake system in a biotin auxotroph of Saccharomyces cerevisiae. Compared with the rate of biotin uptake in $S$. cerevisiae, that of $L$. starkeyi was slow (Fig. 3 ) but the rate is considered to be sufficient to support normal growth in L. starkeyi because the mean generation time of the organism is longer than that of $S$. cerevisiae.

The amount of biotin taken up varied greatly with culture age (Fig. 6). In a preliminary experiment of growth studies in L. starkeyi, the ratio of dead cells to total cell number in a medium increased gradually, both in the retardation phase and in the stationary phase of growth. The decrease in the uptake capacity of stationary-phase cells may at least partly represent a reduced percentage of living cells.

An important aspect of any permeation study is to determine whether the transported molecules are taken up against a concentration gradient $(13,14)$. If great differences in concentration exist between the internal and external cellular environment, it may indicate that substances are taken up by active transport. The intracellular biotin concentration was calculated from the results of the previous paper (2). On the basis of $0.00414 \mathrm{ml}$ of apparent volume per $\mathrm{mg}$ of dry cells (11), the cellular biotin concentration exceeded that found extracellularly by a factor of 104.1. Biotin uptake in L. starkeyi was stimulated by glucose or other energy-yielding substances, and was observed only when the cells were incubated under aerobic conditions (Fig. 1, Table 1). Biotin uptake was markedly inhibited by various respiratory inhibitors (Table 3 ). These results make it clear that the biotin uptake in L. starkeyi is an energy-requiring active transport system.

\section{REFERENCES}

1) W. Ch. Slooff, In The Yeasts, ed. by J. Lodder, North-Holland Publishing Company, Amsterdam, London (1970), p. 379.

2) Y. Uzuka, T. Naganuma, K. Tanaka, and Y. Odagiri, J. Gen. Appl. Microbiol., 20, 197 (1974).

3) Y. Uzuka, T. Naganuma, and K. Tanaka, J. Gen. Appl. Microbiol., 20, 277 (1974). 
4) T. O. Rogers and H. C. Lichstein, J. Bacteriol., 100, 557 (1969).

5) K. Akiyama, Y. Uzuka, and K. Tanaka, Rep. Fac. Eng. Yamanashi Univ., 22, 93 (1971), in Japanese.

6) L. J. Wickerham, Tech. Bull. No. 1029, U. S. Department of Agriculture, Washington, D. C. (1951).

7) Y. KASHIDA, Radioisotopes, 16, 85 (1967).

8) J. R. WAller and H. C. Lichstein, J. Bacteriol., 90, 843 (1965).

9) R. C. Wood and G. H. Hitchings, J. Biol. Chem., 234, 2381 (1959).

10) T. Kawasaki, I. Miyata, K. Esaki, and Y. Nose, Arch. Biochem. Biophys., 131, 223 (1969).

11) M. Sodeyama, Y. Uzuka, and K. Tanaka, J. Agr. Chem. Soc. Japan, 46, 495 (1972) in Japanese.

12) M. Sodeyama, Y. Uzuka, and K. Tanaka, J. Agr. Chem. Soc. Japan, 46, 503 (1972) in Japanese.

13) V. P. Cirillo, Ann. Rev. Microbiol., 15, 197 (1967).

14) A. Kepes and G. N. Cohen, In The Bacteria, IV ed. by I. C. Gunsalus and R. Y. Stanier, Academic Press Inc., New York (1962), p. 179. 